\title{
Relating Teacher PCK and Teacher Practice Using Classroom Observation
}

\author{
Erik Barendsen $^{1}$ (D) Ineke Henze $^{2}$
}

Published online: 21 September 2017

(C) The Author(s) 2017. This article is an open access publication

\begin{abstract}
Science teachers' pedagogical content knowledge (PCK) has been researched in many studies, yet little empirical evidence has been found to determine how this knowledge actually informs teachers' actions in the classroom. To complement previous quantitative studies, there is a need for more qualitative studies to investigate the relationship between teacher knowledge (as formulated by the teacher) and classroom practice, especially in the context of an educational innovation. In this study we explored a possible way to investigate this relationship in an in-depth and systematic fashion. To this end, we conducted a case study with a chemistry teacher in the context of the implementation of a context-based science curriculum in The Netherlands. The teacher's PCK was captured using the Content Representation form by Loughran, Mulhall, and Berry. We used an observation table to monitor classroom interactions in such a way that the observations could be related to specific elements of teachers' PCK. Thus, we were able to give a detailed characterization of the correspondences and differences between the teacher's personal PCK and classroom practice. Such an elaborate description turned out to be a useful basis for discussing mechanisms explaining the relationship between teachers' knowledge and teachers' actions.
\end{abstract}

Keywords Teacher PCK $\cdot$ Teacher practice $\cdot$ Classroom observation $\cdot$ Science education

Erik Barendsen

e.barendsen@cs.ru.nl

Ineke Henze

f.a.henze-rietveld@tudelft.nl

1 Radboud University and Open University of the Netherlands, Toernooiveld 212, 6525 EC Nijmegen, The Netherlands

2 Delft University of Technology, Lorentzweg 1, 2628 CJ Delft, The Netherlands 


\section{Introduction}

\section{Teacher Knowledge}

In recent history, there have been different ways to view teacher knowledge and its role in teacher practice.

Halfway through the previous century, a substantial part of education research focused on developing generic knowledge for teachers and translating this into guidelines for behavior in the classroom. At somepoint, this behaviorist view began to be criticized because of its reductionist view on teaching (Doyle 1990).

From the $1980 \mathrm{~s}$ on, in the slipstream of the change towards a cognitivist and constructivist perspective on learning and teaching, teacher knowledge came to be perceived as more personal. Moreover, teachers' knowledge was considered a crucial determinant of teachers' actions (e.g., Clark and Peterson 1986; Hoyle and John 1995; Verloop 1992). This knowledge of teachers (Fenstermacher 1994) became viewed as the core of a teacher's professionalism and as a filter for interpreting new experiences, thus guiding a teacher's activities in concrete and specific situations (Brown and McIntyre 1993; Pajares 1992; Putnam and Borko 1997). In this new perspective, the relationship between knowledge and behavior is reciprocal by nature, as knowledge development is guided by experiences in classroom practice and interactions with colleagues (Clarke and Hollingsworth 2002). Thus, it is considered worthwhile to investigate teachers' thinking and decision making processes, as well as their practical knowledge and beliefs (Verloop et al. 2001).

With respect to research on teacher knowledge, Shulman (1986) mentioned a blind spot concerning subject matter content, referring to the common emphasis on how teachers managed their classrooms, organized activities, structured assignments, ascribed praise and blame, formulated the levels of their questions, and so on. What was missing, according to Shulman, were questions about the content of the lessons taught, the questions asked, and the explanations offered. So, he introduced the construct of Pedagogical Content Knowledge (PCK) as a particular form of content knowledge, which goes beyond knowledge of subject matter per se to the dimension of subject matter knowledge for teaching. This new type of teacher knowledge represents "the blending of content and pedagogy into an understanding of how particular topics, problems, or issues are organized, represented, and adapted to the diverse interests and abilities of learners and presented for instruction" (Shulman 1987, p. 8). This definition implies that PCK encompasses comprehension and pedagogical reasoning, transformation and practice (Shulman 1987), thus it comprises both teachers' understanding and their enactment. The former can be seen as a knowledge base used in planning for and delivery of topic-specific instruction (Gess-Newsome 2015, p. 36) and is sometimes referred to as knowledge-on-action (Park and Oliver 2008). This knowledge is explicit and can be found, for example, in instructional plans, or can be elicited directly from teachers. What the teacher does in the classroom (enactment) is informed by knowledge-on-action but also involves decision making on the spot and therefore requires a more dynamic kind of knowledge called knowledge-in-action (Park and Oliver 2008). This knowledge-in-action is both enacted and developed during teaching by reflection-in-action (Schön 1983). This illustrates the reciprocal (i.e., non-linear) dependency between PCK development and PCK enactment. Knowledge-inaction is sometimes explicit but is more often tacit and more difficult to capture (Park and Oliver 2008). 


\section{Elements of PCK}

In research on teacher knowledge focusing on specific content domains, many investigators have elaborated on Shulman's work and conceptualized PCK in multiple ways. Most scholars agreed on Shulman's (1986) two key components within PCK: knowledge of representations of subject matter, and understanding of specific learning difficulties and student (alternative) conceptions. Incorporating various attributes or characteristics has resulted in a range of PCK models over the years (e.g., Ball et al. 2008; Cochran et al. 1993; Fischer et al. 2012; GessNewsome 1999; Magnusson et al. 1999; Park and Chen 2012; Park and Oliver 2008).

The most cited model is that of Magnusson et al. (1999), which adds three additional components to Shulman's definition of the construct of PCK. Four of these components correspond to the following elements of content-specific pedagogy (which we refer to as M1 to M4, respectively): goals and objectives for teaching a specific topic in the curriculum (M1), students' understanding of this topic (M2), instructional strategies concerning this topic (M3), and ways to assess students' understanding of this topic (M4). These four elements are universal in the sense that they appear in a variety of general pedagogical models in literature and in teacher education materials (e.g., Van Gelder et al. 1973). Because of their pedagogical completeness and simplicity, we will use Magnusson et al.'s M1 to M4 to characterize elements of content-specific pedagogy and the corresponding PCK elements.

Magnusson et al. (1999) do not connect these different elements within their PCK model. In our opinion, however, relationships between these elements (i.e., internal coherence or logic) are crucial (cf. Van Driel and Henze, 2012). Indeed, the elements M1 to M4 need to be interconnected to enable effective scaffolding of students' learning (cf. Park and Chen 2012). In our view, the strength of these interconnections is an indicator for the quality of a teacher's PCK, as well as indicating the extents of the respective elements. That is, strong connections contribute to strong PCK. In this, we respect Shulman's (1987, p. 15) model of pedagogical reasoning and action. This model implies that teachers' knowledge of students' understanding of a specific topic, in a specific context, provides grounds for choices and actions with regard to goals, instructional strategies, and ways to assess students' understanding that correlate with each other and with the specific situation. Although the four elements of PCK are mutually related, they can be investigated separately (Henze et al. 2008).

\section{PCK and Its Role in Teacher Practice}

Already by the 1990 s, PCK had been recognized as a knowledge base necessary for the effective teaching of science subjects. This view was expressed in many educational reform documents (e.g., American Association for the Advancement of Science 1993; National Research Council 1996) and has led to several attempts aimed at evaluating teachers' PCK and classroom actions in the context of a professional development program, or establishing formal assessment procedures. The results of the few large-scale studies investigating the relationship between teacher PCK and classroom actions (e.g., Baumert et al. 2010; GessNewsome et al. 2011) are far from conclusive. For instance, Baumert et al. (2010) found a positive relation between $\mathrm{PCK}$ - measured with a test - and instructional quality - measured by assessment of teacher-constructed assignments, a student survey on quality of individual learning support and classroom management. On the other hand, Gess-Newsome et al. (2011) failed to find a correlation between PCK - measured with a test - and classroom teaching measured with observational rubrics. 
Indeed, the relationship between teacher PCK and what the teacher does in the classroom is inherently complex since their interplay involves both knowledge-on-action and knowledgein-action. Moreover, investigating the nature and underlying mechanisms of this interdependency is non-trivial since part of the teacher's knowledge is tacit and hard to elicit.

\section{Elicitation of PCK}

Over the last 25 years, scholars have captured and portrayed science teachers' PCK and PCK development in different ways, using a variety of tools. Many studies were smallscale and qualitative in nature. For instance, Loughran et al. (2004) investigated expert high school teachers' PCK for a specific topic using interviews, structured by a so-called Content Representation (CoRe) form. In addition, Pedagogical and Professional experience Repertoires (PaP-eRs) were developed from detailed descriptions provided by teachers, as a means to offer insights into a teacher's pedagogical reasoning in the context of action that was missing in the CoRe. They also used classroom observations as prompts for attempting to "unpack" the teachers' PCK through stimulated recall. CoRe and PaPeRs were also used by other investigators (e.g., Nilsson and Loughran 2012; Padilla et al. 2008). To capture PCK development in beginning teachers, Friedrichsen et al. (2009) used interview transcripts from teachers as primary data sources, and lesson plans, lesson artifacts, videotapes of classroom teaching, and field notes from observation as secondary data sources. In addition Henze et al. (2008), De Jong et al. (2005) and Wongsopawiro (2012) have used a variety of data sources in their studies on PCK and PCK development both in beginning and experienced teachers. These include audio recordings of pre- and post-lesson interviews with individual teachers and of discussions between teachers (e.g., during workshops in a teacher education program), and written materials made by teachers, such as lesson plans, reflective lesson reports (e.g., based on a teacher watching a video of a lesson of himself or herself), action research plans, and action research reports. For data analysis, categorizing and coding of statements by teachers, either written or oral, was used. Comparison between individual teachers led to the identification of types of PCK and PCK development (Henze et al. 2008; Wongsopawiro 2012). All such small-scale, indepth, qualitative studies have in common that they were aimed at portraying PCK as teachers' subjective understandings of their practice (i.e., knowledge-on-action). Video recordings and observations of classroom teaching were used to support this portrayalthat is, for stimulated recall interviews or for verification of oral and written data sourcesrather than as primary data sources to capture teachers' knowledge-in-action.

\section{Aim of the Study}

\section{Rationale}

The inherent complexity of the relation between teachers' knowledge (i.e., PCK-on-action) and teachers' practice and the lack of consistent findings in the large-scale studies on this relation support the idea that systematic, in-depth, small-scale studies on the interplay of PCKon-action and classroom practice are in place.

We aimed to conduct such an in-depth case study to compare teacher PCK-on-action with teacher classroom practice (as a manifestation of PCK-in-action) by unraveling each in terms 
of the constituting pedagogical elements M1 to M4 and their interrelationships, mentioned in the introduction.

As to the methodology, we intend to use classroom observations as a primary data source instead of as input for stimulated recall, as is common practice in existing small-scale qualitative studies. Rather than the normative approach followed in the previously mentioned large-scale studies, we take a descriptive and analytical point of view. As a consequence, we cannot use existing surveys (Baumert et al. 2010) or rubrics (Gess-Newsome et al. 2011) to capture teachers' classroom behavior. Therefore, we explore a new way to investigate classroom practice and its relationship with teacher PCK-on-action in a systematic in-depth fashion.

In summary, with this study we intend to contribute to theories on science teachers' PCK as well as to methodologies for investigating this complex construct. Moreover, we think that this type of qualitative research on the relationship between PCK-on-action and the classroom context will contribute to the current debate on the nature of the concept of PCK and its development (Gess-Newsome 2015).

Below, we will describe the context of our study and translate the general aim into research questions specific for this context.

\section{Context of the Study}

This study is part of a bigger project focusing on the relationship between teacher knowledge and teacher practice. We have chosen to investigate this relationship in the current instructional paradigm of context-based science education (Gilbert 2006). Although there is ample research on PCK in science education, research on PCK in context-based teaching and learning has been underexposed. Apart from the present study focusing on a teacher's PCK and its enactment in the classroom, we examined the relationship between the teacher's PCK and students' cognitive learning outcomes (Henze and Barendsen 2013) and with students' attitudes towards science (Barendsen and Henze 2015).

In Dutch science education, a context-based approach has been adopted in which science content is connected with social, experimental, theoretical, and professional contexts (Gilbert 2006) which appeal to a broad group of students. The context-based approach is inspired, among other things, by the need to change students' attitudes towards science and make science more meaningful and more relevant to students (Bennett and Holman 2002). Context-based science learning involves a transition from getting an overview of the conceptual products to the functional use of concepts in relation to a certain relevant context (Westbroek 2005). This meaningful learning requires that constructivist approaches to science teaching are applied (cf. Mayer 2002; Ogborn 1997), notably including an emphasis shift from teacher control to student initiative. Context-based science courses would be effective in supporting learning if the student both recognizes and values the context within which tasks are set, and if the learning environment is such that discussion of ideas and their interrelationships can readily take place (Gilbert et al. 2011).

There is some research on teacher development in Dutch context-based chemistry education (Coenders 2010; Stolk 2013), but more in-depth studies are still needed.

Participant The subject of the present study is a chemistry teacher in his mid 40s with almost 20 years of teaching experience in secondary education. He holds a Master's degree in chemistry and a full teacher qualification for chemistry in secondary education. 
This teacher is known as innovation-minded and has been involved in various activities promoting constructivist learning and teaching. Furthermore, he has taken part in developing a lesson module on (Poly) Lactic Acid for Grade 9 students, within a professional learning community of secondary chemistry teachers and educational and subject matter experts (i.e., one teacher educator and a group of professionals from the chemical and biotechnical industries). The authors of this paper did not participate in this community.

In our initial investigation, prior to the present study, we verified the teacher's position with respect to the role of contexts in science education, using the questions of the curriculum emphasis questionnaire developed by Van Driel et al. $(2005,2008)$ as a theoretical basis to identify the teacher's beliefs with respect to the context-based chemistry curriculum in Dutch secondary education. The design of this questionnaire is based on the curriculum emphases: fundamental chemistry (FC), chemistry, technology, and society (CTS), and knowledge development in chemistry (KDC). FC corresponds to the belief that theoretical notions should be taught first, because such notions can later on provide a basis for understanding the natural world, and are needed for the students' future education. CTS implies an explicit role of technological and societal issues within the chemistry curriculum. Finally, KDC is connected with the idea that students should learn how knowledge in chemistry is developed in sociocultural contexts, so that they learn to see chemistry as a culturally determined system of knowledge, which is constantly developing. The questionnaire includes three scales, one for each emphasis. The scale for FC contains 16 items, CTS also contains 16 items, and KDC contains 14 items. Each of the items is to be scored on a five-point scale (1 to 5). We obtained the teacher's curriculum emphasis, expressed as the mean scores on the three scales. Within each scale, Van Driel et al. (2008) identified the items with the highest item-total correlations (FC, 4 items; CTS, 4 items; KDC, 5 items). We calculated the mean scores of our teacher on these selected items. The results of these calculations indicate that, on the whole, all three curriculum emphases were positively evaluated by the teacher. However, the curriculum emphasis chemistry, technology, and society (CTS) received the highest mean score, namely 4.00, whereas the support of curriculum emphases fundamental chemistry (FC) and knowledge development in chemistry (KDC) were lower: 3.75 and 3.40, respectively. These scores are significantly higher on CTS and lower on FC and KDC than those of the teachers in the study by Van Driel et al. (2008).

From the above, we concluded that the teacher's pedagogical and curricular beliefs are in line with the context-based instructional paradigm. Therefore we expect that these beliefs will not act as "obvious" negative filters (Gess-Newsome 2015) for the teacher's activities in the classroom when teaching in a context-based way. Thus, there are no a priori reasons for a substantial difference between his teaching practice and his articulated PCK. This makes our teacher a valuable subject for our study.

Lesson Module The abovementioned lesson module on lactic acid was the practical context of our study. This specific lesson module was constructed according to the context-based teaching approach and emphasizes the role of (poly) lactic acid in students' personal lives, in their environment, and in industry. During our study, the teacher taught the module for the third year. The class consisted of 16 students in Grade 9, who attended the module lessons between March and May. Table 1 presents a general overview of the module contents: themes, specific topics/ conceptual content, contexts, and student activities. Classroom instruction includes a variety of methods, such as demonstration, plenary instruction, student paper work, and student lab work. 
The module is shaped around three themes that are interconnected through the central concept of Lactic Acid.

Within Theme I, the contexts of "human body" and "personal environment" (especially food) play a role at a distance (Bruning and Michels 2013). That is, the selection of initial concepts (i.e., lactic acid, acidification, aerobic and anaerobic oxidation, fermentation) is based on these contexts. Subsequently, however, the lesson material proceeds according to the "traditional" conceptual structure, that is, all concepts related to lactic acid (e.g., acids and alkalis, $\mathrm{pH}$, indicator, titration) are taught independently of any specific context. Teaching and learning activities involved lectures, assignments, and labwork with food as an illustrative context (see Table 1 for details).

Theme II is shaped around a technological context, namely "biotechnology" (especially production of food, bioethanol, biodiesel) as a central context, that is, all concepts in the lesson material relate to the chosen context, according to the "need to know" principle (Bruning and Michels 2013; Gilbert et al. 2011). As a consequence, the context provides the main coherence between the concepts (e.g., industrial fermentation, micro-organisms, biomass, closed carbon cycle, sustainability). Learning activities consisted of student work without teacher assistance, for example watching a movie and reading articles.

Within Theme III, the structure of the lesson material completely follows a traditional conceptual structure related to lactic acid (in this case including poly lactic acid, polymerization, macro molecules, crosslinks, bioplastic). Biotechnological and societal

Table 1 Overview of the module content

\begin{tabular}{|c|c|c|c|}
\hline Theme & $\begin{array}{l}\text { Specific topics/conceptual con- } \\
\text { tent }\end{array}$ & Contexts & Students' activities \\
\hline $\begin{array}{l}\text { I. Lactic Acid: } \\
\text { features } \\
\text { and } \\
\text { applica- } \\
\text { tions (2 } \\
\text { lessons) }\end{array}$ & $\begin{array}{l}\text { Lactic acid (LA), acidification, } \\
\text { aerobic and anaerobic } \\
\text { oxidation, glycolysis, acids } \\
\text { and alkalis, pH, indicator, } \\
\text { titration, fermentation }\end{array}$ & $\begin{array}{l}\text { Human body: sore muscles, } \\
\text { cavities (tooth decay) } \\
\text { Personal environment: food }\end{array}$ & $\begin{array}{l}\text { Labwork: making yogurt, } \\
\text { measuring pH (various } \\
\text { solutions), measuring LA in } \\
\text { buttermilk, making } \\
\text { sauerkraut from white } \\
\text { cabbage, measuring acid in } \\
\text { vinegar (titration) } \\
\text { Completing assignments } \\
\text { Doing calculations: involving } \\
\text { concentrations/amounts of } \\
\text { acid in diluted solutions }\end{array}$ \\
\hline $\begin{array}{l}\text { II. Synthesis } \\
\text { of lactic } \\
\text { acid ( } 2 \\
\text { lessons) }\end{array}$ & $\begin{array}{l}\text { Industrial fermentation, } \\
\text { micro-organisms, biomass, } \\
\text { closed carbon cycle, } \\
\text { sustainability, green (bio } \\
\text { based) chemicals }\end{array}$ & $\begin{array}{l}\text { Biotechnology: food, } \\
\text { bioethanol, biodiesel }\end{array}$ & $\begin{array}{l}\text { Watching a movie } \\
\text { Completing assignments } \\
\text { Reading articles }\end{array}$ \\
\hline $\begin{array}{l}\text { III. Poly lactic } \\
\text { acid and } \\
\text { bioplastics } \\
\text { (3 lessons) }\end{array}$ & $\begin{array}{l}\text { Polymerization, macro } \\
\text { molecules, crosslinks, hard } \\
\text { and soft plastics, poly lactic } \\
\text { acid (PLA), plastics, } \\
\text { bioplastic }\end{array}$ & $\begin{array}{l}\text { Industrial } \\
\text { Biotechnology/Society: } \\
\text { degradable plastics, } \\
\text { packing materials (for } \\
\text { fruit, vegetables), } \\
\text { disposable } \\
\text { glasses/plates/cutlery, } \\
\text { Medicine/Human Body: } \\
\text { drugs, soluble suture, } \\
\text { artificial knee, hip etc., } \\
\text { cosmetics (PLA fillers) }\end{array}$ & $\begin{array}{l}\text { Labwork: investigating } \\
\text { features of plastics, } \\
\text { developing a physical } \\
\text { model of a polymer (plastic) } \\
\text { molecule } \\
\text { Reading articles } \\
\text { Completing assignments }\end{array}$ \\
\hline
\end{tabular}


context, such as "packing materials," drugs, and cosmetics, serve as illustrations or direct applications of the concepts (Bruning and Michels 2013). Students are expected to attend lectures, to complete assignments, and to investigate features of (bio)plastics during labwork.

\section{Research Questions}

In this context, we investigated the relationship between the teacher's articulated PCK-onaction and the teacher's classroom practice (as a manifestation of his PCK-in-action). We formulated the following research questions.

1. How can the teacher's articulated PCK-on-action with respect to the module content be portrayed in terms of the underlying pedagogical elements M1 to M4 and their interconnections?

2. How can the teacher's classroom practice be described in the same terms?

3. How can the relation between the teacher's articulated PCK-on-action and the teacher's classroom practice be characterized in these terms?

\section{Methods}

We examined the teacher's $P C K$-on-action by interviewing him about his understanding of the learning and teaching of the lesson module on (Poly) Lactic Acid. The questions were taken from the CoRe form (Loughran et al. 2004). This interview took place just before the teaching of the lesson module.

In order to capture the teacher's practice, we recorded all module lessons. Classroom interactions were recorded on video using two cameras, one at the front and one at the back of the classroom. We constructed an observation table to observe the teacher's classroom actions. The concrete observational items include aspects of constructivist context-based science education. For our study we selected those video segments in which the teacher was clearly visible and that were of substantial length (at least $10 \mathrm{~min}$ ). We completed the observation table for all segments in our corpus.

We used the four pedagogical elements of the model by Magnusson et al. (1999) and their interconnectedness as the basis of our analysis of the interview responses and the classroom observations. See Fig. 1.

After analyzing these data sources separately (for the research questions 1 and 2), the framework was used to systematically describe the relation between the teacher's PCK-onaction and his classroom practice (Research Question 3).

Fig. 1 Analytical framework

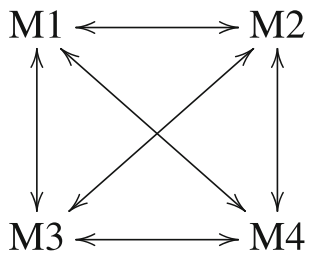


We give the details of the method below. We specify our data collection and analysis procedure organized by the research questions.

\section{Methods-Research Question 1}

Interview We investigated the teacher's PCK-on-action using a semi-structured interview prior to his teaching of the module. We focused on the teacher's "important ideas and concepts" attached to the topic of (Poly) Lactic Acid and his subjective representations of these, using the questions in the "Content Representation" form (Loughran et al. 2004). The items of this Content Representation form (further: CoRe) cover the four PCK elements (M1 to M4) mentioned in the Introduction section, see Table 2. During the interview, one of the researchers wrote down the teacher's responses in a table organized by the "big ideas" and the CoRe questions for each of these. Respondent validation (cf. member checking, Lincoln and Guba 1985) was applied after the interview: the completed CoRe table was verified and extended where necessary by the teacher.

Analysis The completed CoRe table was analyzed by coding the teacher's statements using analytic codes (Gibbs 2007). The units of analysis consisted of coherent statements or explanations about a single educational issue within the cells of the CoRe table (i.e., the answers to the CoRe questions). Typically these units are the complete contents of such a cell, but occasionally the teacher addressed more than one possible instructional strategy (CoRe question 8) or several difficulties related to students (CoRe question 5). In such cases, the answers gave rise to several units of analysis.

The codes were taken from our analytical framework (Fig. 1), for example code M2 for statements in which students' understanding was addressed, and M3 for statements containing instructional strategies.

To facilitate a more detailed analysis of the CoRe table and to prepare for a comparison with the observed practice, we refined the analytic codes using the following subcodes (indicated in italics below).

Table 2 PCK elements and CoRe items

M1. Knowledge about goals and objectives of teaching 1. Important science ideas/concepts concerning this a specific topic in the curriculum theme (topic)?

To be answered for each individual idea:

2. What you intend students to learn about this idea?

3. Why is it important for students to know this?

4. What else do you know that you may not intend students to know yet?

M2. Knowledge of students' understanding of this specific topic

M3. Knowledge about instructional strategies concerning the specific topic

M4. Knowledge about ways of assessing the specific topic
5. Knowledge about students' thinking which influences your teaching of this idea?

6. Difficulties/ limitations connected with teaching this idea?

7. Other factors that influence your teaching of this idea?

8. Teaching procedures (and particular reasons for using these to engage with this idea)?

9. Specific ways for ascertaining students' understanding or confusion around this idea? 
As to the Goals and objectives (M1), we took the classical trichotomy of knowledge, skills, and attitudes, based on Bloom's (1956) Taxonomy of Learning Domains: the cognitive domain, the psychomotor domain, and the affective domain. Since attitudes are explicitly mentioned, we found Bloom's taxonomy to fit better to the context-based approach than alternative classifications such as, for example, Hodson's (1992) goals for science education: to learn science, to do science, and to learn about science. Indeed, attitude development is an important aspect of context-based education.

We subdivided the knowledge category into science concepts (the scientific theory), personal life (topics from the personal environment that have scientific aspects), society and technology (topics from the social environment, society, and industry that have scientific aspects), and epistemology (nature and origin of scientific knowledge, historical models, and theories). This categorization is based on recent curriculum innovations, and on the curriculum emphasis taxonomy (i.e., positions about what the science curriculum should emphasize) by Van Driel et al. (2008).

The skills category applies to physical (motoric) actions, for example "titration." We considered cognitive (mental) skills, such as "balancing a chemical reaction equation," to belong to the category of knowledge.

The category of attitude concerns attitudes and opinions with respect to (parts of) the chemistry discipline or decisions and reasoning with respect to societal matters connected to the discipline, for example "opinions about sustainable production," or the "recognition of the importance of safety in the lab".

Thus, examples of codes for Goals and objectives are as follows: M1-knowledge-personal life, M1-skills.

As to Students' understanding (M2), we distinguish between statements referring to students' knowledge, their skills, their attitudes and learning preference. Examples of codes include the following: M2-knowledge, M2-attitudes.

As to the Instructional strategies (M3), a typical list of teaching methods was taken and some refinements were made according to the specific constructivist foundations of the curriculum innovation, notably to distinguish between different roles of the teacher during student assignments. The item categories are as follows: lecturing, interactive instruction, demonstration, student work, student debate, and other activities. Moreover, in order to mirror the emphasis shift related to constructivist teaching and learning mentioned in the Introduction section, we used subcodes related to control, distinguishing between teacher control and student initiative, respectively. Examples of codes are as follows: M3-lecturing, M3-student work, M3control-teacher.

As to assessment (M4), we used a simple division into questions (e.g., elicitation of students' preconceptions), assignments (e.g., an exercise to apply previously explained chemical concepts, theory), inspecting students' products (e.g., lab log, report), and final tests. Examples of codes are as follows: M4-assignments, M4-final test.

The coding was done by the two authors separately. Then the results were compared and discussed in case of any differences.

In order to portray the teacher's PCK-on-action in terms of the underlying pedagogical elements, we summarized the teacher's responses coded with M1 to M4 (using the subcodes per element to further characterize the teacher's PCK-on-action). The interconnections 
between PCK elements M1 to M4 were analyzed by summarizing statements in which multiple PCK elements were addressed (e.g., both M1 and M3), using the subcodes in the same way as before.

\section{Methods-Research Question 2}

Observation Table We used classroom observations to investigate the teacher's practice. Like we did for the teacher's PCK-on-action, we aim to portray the teacher's practice in terms of the constituting pedagogical elements M1 to M4. Therefore, we applied structured observation based on these elements, rather than a more "open" unstructured observation procedure. Moreover, using a structured observation table makes it easier to carry out simple quantitative analysis (counting element occurrences) and to identify patterns indicating interconnections between pedagogical elements.

As a starting point in the construction of the observation table, we selected those pedagogical elements that appeared suitable for observation in practice, and identified observational items for each of these, as follows (see Table 3). For Goals and objectives (M1) we observed Lesson content, for Instructional strategies (M3) we observed Instructional methods and Control, and for Assessment (M4) we observed Check of students' understanding. We believe that Students' understanding cannot be observed directly, but rather as part of the teacher's interactions with students via the observational items Instructional methods and Check of students' understanding.

The observation categories within the observational items are as follows. The items are the same as the subcodes in the CoRe analysis (Research Question 1), with some modifications. These involve addition of specific observable aspects (e.g., connected to organizing students' work) and discarding non-observable events (e.g., final tests).

As to the Lesson content item, the categories were knowledge (with subcategories science concepts, personal life, society and technology, epistemology), skills, and attitudes.

As to the Instructional methods, we distinguished lecturing, interactive instruction, demonstrating, instructing for student work, guiding (or organizing unguided) student work, concluding student work, chairing student debate, and other activities.

As to Control, we distinguish teacher control and student initiative, respectively.

As to Check of students' understanding, we distinguished questions and assignments.

The constructed observation table was tested for completeness and usability by coding random 10 minute samples of the video recordings. For each observational item, we assigned fitting categories to subsequent 1 minute intervals. The researchers' agreement

Table 3 Pedagogical elements and observational items

\begin{tabular}{ll}
\hline Pedagogical elements (Magnusson et al. 1999) & Observation table \\
\hline M1. Goals and objectives of teaching a specific topic in the curriculum & Lesson content \\
M2. Students' understanding of this specific topic & - \\
M3. Instructional strategies concerning the specific topic & Instructional method \\
& Control \\
M4. Ways of assessing the specific topic & Check \\
\hline
\end{tabular}


was checked after every two or three samples. Wherever necessary, the descriptions of the item categories were adapted (cf. Weber 1990), for example to better distinguish the categories of Lecturing and Interactive instruction. To facilitate a subsequent in-depth analysis of our observations, we added a notes sheet to our observation table in order to record interesting content details with respect to the different observations. For example, the content of the teacher's instructions for student work, or the content of check questions and assignments. The observation table, the notes sheet, and the final category descriptions with more examples can be found in Appendix A.

For the selected video recordings in our corpus, we completed the observation table, again assigning the fitting categories to 1 minute intervals.

Analysis For the completed observation tables, we first performed a simple frequency analysis for each observational item (cf. Weber 1990) by adding up the scores for each of the corresponding observational categories per video segment.

Furthermore, we looked for patterns within each observational item, that is, distribution, order, and alternation of assigned categories over time.

Then we looked for patterns between observational items, that is, correspondence between assigned categories, for example, co-occurrence of assigned categories science concepts (within item Lesson content) and interactive instruction (within Instructional methods).

At this stage we did not use the notes sheets yet, so the analysis was only based on assigned categories per time interval and their totals over all video segments.

Subsequently, we conducted a further in-depth content analysis of the observed classroom actions. In this in-depth analysis we aimed at refining and explaining the found patterns, as well as discovering new patterns. This analysis was performed on the video recordings, using the already found patterns and the remarks on the notes sheets as pointers to scenes that seemed valuable to analyze in more depth.

Together, the descriptions of the patterns can be used to characterize the teacher's classroom practice in terms of the underlying pedagogical elements M1 to M4 and their interrelationships. Using Table 3 we can identify which patterns are relevant for characterizing each of the pedagogical elements, as well as each of their interrelationships: see Table 4.

Table 4 Pedagogical elements and observational patterns

Pedagogical elements and interrelationships

Observational patterns

M1: goals and objectives

M2: students' understanding

Interconnection M2-M1

M3: instructional strategies

Interconnection M3-M1

Interconnection M3-M2

M4: assessment

Interconnection M4-M1

Interconnection M4-M2

Interconnection M4-M3
Lesson content patterns

Instructional methods patterns, Control patterns,

Instructional methods $\leftrightarrow$ Control patterns

Instructional methods $\leftrightarrow$ Lesson content patterns

Check patterns

Check $\leftrightarrow$ Lesson content patterns

Check $\leftrightarrow$ Instructional method patterns,

Check $\leftrightarrow$ Control patterns 


\section{Methods-Research Question 3}

The results of the analyses for the research questions 1 and 2 provide us with a characterization of both the teacher's PCK-on-action and his classroom practice, consisting of descriptions in terms of each of the pedagogical elements M1 to M4 and their interrelationships. The relation between the PCK-on-action and classroom practice can now be analyzed by a pairwise comparison of each of these descriptions.

\section{Results}

In this section we present our findings, again ordered by the research questions.

\section{Results-Research Question 1}

Below, we portray the teacher's PCK-on-action in terms of the pedagogical elements M1 to M4 and their interconnections. To this end, we summarize the teacher's responses for each element and interconnection. The descriptions of the interconnections always follow the discussion of the respective single elements.

We illustrate our findings with quotations taken from the CoRe table, with attached the subcodes assigned in the analytic coding process (where applicable). These quotations have been translated from the original Dutch.

Goals and Objectives (M1) Prior to teaching the context-based module, the teacher expressed the need to change students' attitudes towards science, specifically addressing sustainability issues with respect to the module subject of lactic acid and poly lactic acid.

"We educate students for tomorrow's society. I want them [students] to get a realistic and honest picture of the role of chemistry in society: green biotechnology, bio plastics, renewable resources. . ." (M1-attitudes)

In particular he stressed the connection of the module content to "personal life," making chemistry more meaningful and relevant to the students.

"I want them to learn that chemistry is connected to their personal lives. A large part of their personal environment consists of chemistry, often without them noticing. I want to 'enlarge' their environment." (M1-knowledge-concepts, M1-knowledge-personal life)

In addition, the teacher appeared eager to show that chemistry has applications in the development of society:

"I want to run meaningful lessons with my students. I insist that they understand what a specific piece of chemistry is used for. Or which applications there are." (M1-knowledge-concepts, M1-knowledge-society) 
"I would like the students to discover this, and thus get a real and fair picture of chemistry" (M1-knowledge-concepts, M1-knowledge-society)

The teacher wants the students to acquire

"[. . . ] lab skills around small activities, for example, making yogurt using lactic acid bacteria" (M1-skills).

Through enactment of the module, the teacher intends to show the students that they, with their knowledge obtained so far,

\section{"[. . . ] can understand pretty difficult science articles." (M1-knowledge-concepts)}

At the same time, he wants to prepare his students to ultimately read the science section of a newspaper, as would be required to study natural sciences in the more advanced grades. He wants them to discover whether this "science track" suits them.

Students' Understanding (M2) The teacher expects that students in his group generally regard the subject of the module as difficult,

"[. . . ] especially difficult for those students that won't choose the 'science track' after this year." (M2-knowledge)

Interconnection M2-M1 With respect to students' learning motivation concerning the context-based module, the teacher thinks the students generally have no a priori interest or ambition to learn about the connection of chemistry to their personal lives.

"At the same time we notice that students have no a priori interest [. . ] in this subject. This gives friction, and at the same time a challenge to enlarge the personal life of a student with respect to this point." (M1-knowledge-personal life, M2-attitudes)

On the other hand, the teacher expects that his students already have a knowledge base and are willing to know about the real-life applications.

"They have already obtained quite some basic knowledge, and they are about to ask "What can we do with that knowledge?' " (M1-knowledge-personal life, M1-knowledge-society, M2-knowledge)

Instructional Strategies (M3) The teacher favors a teaching strategy in which students pursue these subjects and questions in a heuristic way instead of following a prescribed "algorithm."

In the teacher's opinion, this takes place in plenary classroom sessions with lots of interaction, in which the blackboard and the students' making notes play an important role.

The teacher emphasized that students should be stimulated to come up in class with relevant subjects and questions. 
"I want to be 'open' to the students and learn from them: some reciprocity. This means talking with the students and critical self-reflection." (M3-interactive-instruction, M3control-student)

Interconnection M3-M1 In the realization of this strategy, the teacher prefers tailoring his approach to a specific group of students, engaging them, teaching them about chemical facts, and challenging them to make sense of this knowledge by themselves. The teacher stresses, however, that the factor "time" is always present in teaching.

"Connecting to the daily life of the specific group of students, then focusing on the chemical facts, and giving meaning by showing their value, or better: letting the students discover this by themselves." (M3-interactive-instruction, M1-knowledge-concepts, M1knowledge-personal life)

Interconnection M3-M2 According to the teacher, many students enjoy discovering things in interaction with the teacher and with other students.

"A considerable number of students love it: discovering how things work in a conversation between teacher and students, instead of finding out things by themselves, as promoted in many context based modules." (M3-interactive-instruction, M2-learning preference)

Assessment (M4) As to monitoring students' understanding, the teacher prefers to use lots of check questions.

"Activating prior knowledge, and asking the students to react on what is written: what does this mean, what have we learned?" (M4-questions)

Interconnection M4-M1 The teacher tends to use the final test only for assessing students' understanding of module concepts.

The teacher prefers not to assess the students' ability to connect these chemistry concepts with their personal lives explicitly, but instead to measure this.

“. . . intuitively, by looking at their eyes. I prefer that these thoughts about 'meaning' and/or value are put into place as naturally as possible." (M4, M1-knowledge-personal life)

In the teacher's opinion, lab skills are best monitored by grading reports, sometimes by inspecting lab logs.

Interconnection M4-M3 According to the teacher, check questions should be applied throughout the classroom sessions in a casual way, to avoid putting to much pressure.

"I do not want to put this pressure on them, like you should be able to do this already. I prefer to do it in a playful way. And then I say to them: oh, nice, that is wonderful, you got it already." (M4-questions, M3-interactive instruction) 
Interconnection M4-M2 This interconnection was not found in the CoRe.

\section{Results-Research Question 2}

Below we report on the findings of the observation of the teacher's classroom practice using the observation table.

Six video recordings matched our criteria for observation (i.e., the teacher was clearly visible and the segment were of substantial length), spanning 240 minutes in total with intervals ranging from 15 to 52 minutes. We coded the selected video recordings, assigning the applicable categories of the observation table to 1 minute intervals. See, for example, Fig. 2 for the codings for a part of Video 2 (minutes 5 to 19). Sometimes a single 1 minute interval contains more than one category. For example, when the teacher discussed acid as a chemical concept and connected this (in the same interval) with tooth erosion due to drinking sodas, both science concept and personal life were marked in the corresponding table row within item Lesson content.

As to the frequency analysis, the cumulative scores (over all recordings) of the observational items are displayed in Table 5. Note that the numbers within each item do not always add up to the length of the segment in minutes (e.g., $3+9 \neq 15$ in Lesson content in Video 1). There can be two possible causes for this. The first reason is the occurrence of multiple categories in the same 1 minute interval mentioned above. The second is that no category was assigned to a 1 minute interval, because a specific item was not visible (e.g., lesson content during student work).

Below, we present the findings of our analysis of patterns within each of the observational items, as well as patterns between observational items.
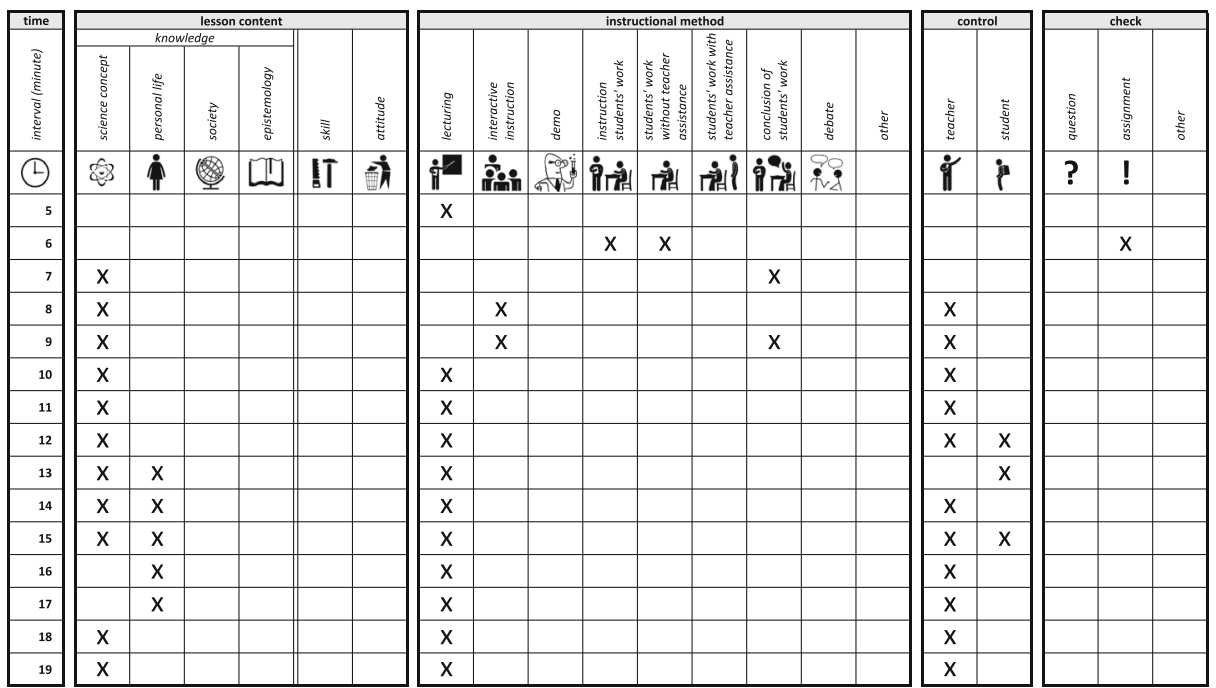

Fig. 2 Completed observation table 
Table 5 Cumulative scores

\begin{tabular}{|c|c|c|c|c|c|c|c|c|}
\hline Video & $\begin{array}{l}\text { Number } \\
\text { Length (min) }\end{array}$ & $\begin{array}{l}1 \\
15\end{array}$ & $\begin{array}{l}2 \\
39\end{array}$ & $\begin{array}{l}3 \\
64\end{array}$ & $\begin{array}{l}4 \\
19\end{array}$ & $\begin{array}{l}5 \\
51\end{array}$ & $\begin{array}{l}6 \\
52\end{array}$ & $\begin{array}{l}\text { Total } \\
240\end{array}$ \\
\hline \multirow[t]{6}{*}{ Lesson content } & Science concept & 3 & 21 & 57 & 18 & 35 & 50 & 184 \\
\hline & Personal life & 9 & 11 & 2 & 3 & 8 & 3 & 36 \\
\hline & Society & & 1 & 2 & & & & 3 \\
\hline & Epistemology & & & & & & & \\
\hline & Skill & & & 5 & & & & 5 \\
\hline & Attitude & & & & & & & \\
\hline \multirow[t]{9}{*}{ Instructional method } & Lecturing & 12 & 14 & 39 & 19 & 38 & 33 & 155 \\
\hline & Interactive instruction & & 3 & 1 & 3 & 8 & 2 & 17 \\
\hline & Demo & 6 & & & & & & 6 \\
\hline & Instruction student's work & 1 & 2 & 2 & & 1 & 5 & 11 \\
\hline & Student's work without teacher assistance & & 7 & & & 4 & 5 & 16 \\
\hline & Student's work with teacher assistance & & & 5 & & 5 & 4 & 14 \\
\hline & Conclusion of student's work & & 3 & 4 & & 2 & 6 & 15 \\
\hline & Debate & & & & & & & \\
\hline & Other & & & & & & & \\
\hline \multirow[t]{2}{*}{ Control } & Teacher & 15 & 29 & 64 & 16 & 42 & 48 & 214 \\
\hline & Student & & 9 & 1 & 3 & 2 & 4 & 19 \\
\hline \multirow[t]{3}{*}{ Check } & Question & & 4 & 3 & & 3 & 10 & 20 \\
\hline & Assignment & 1 & 1 & & & 1 & & 3 \\
\hline & Other & & & & & & & \\
\hline
\end{tabular}

For each of the observational items and combinations of these, we will describe both the results of the first analysis stage (without using notes sheets) and the results of the second, more in-depth stage. We illustrate the findings of the in-depth analysis by quotations from the lesson recordings. Again, quotations have been translated from Dutch into English. In the transcriptions, T stands for teacher, whereas S, S1, S2, etc. indicate students.

Similar to the description of the results for Research Question 1, discussions of the patterns between observational items always follow those of the patters within the respective single observational items.

Lesson Content Patterns The video segments contain a mix of conceptual (i.e., chemical concepts) and contextual (i.e., personal life, society, and technology) knowledge content, in which the conceptual content prevailed ( $81 \%$ of all content scores). Personal life contexts appeared more frequently than society and technology contexts.

Skills were addressed only a few times, which could be explained by the fact that the recordings concerned the classroom instead of the lab. Students' attitudes towards science or chemistry were hardly ever addressed. Epistemological content was not observed at all.

The observed alternation of conceptual and contextual knowledge content showed that chemical concepts were, generally, not embedded in personal, societal, or technological contexts. The segment corresponding to Fig. 2 is one of the few exceptions.

As mentioned earlier, the lessons mainly concerned chemistry concepts. These concepts belong to the Themes I and III: anaerobic oxidation, $\mathrm{pH}$, acid, base, polymerization, macromolecules. Related contexts appeared less frequent. The contexts found in the recordings were mainly taken from personal life: yogurt, muscle pain, coca cola, soap, dental erosion. They were discussed after treatment of the concepts involved. The only exception to this rule was the production of lactic acid in muscles which was discussed before introduction of lactic acid as a chemical concept. In fact, the 
module was kicked off by a demonstration in which students were placed in front of the classroom, their arms stretched in front, holding a stack of heavy books until they could not hold anymore. Classmates were instructed to keep track of the time. See Table 1.

$\mathrm{T}$ in the forthcoming lessons I want you to be able to tell me how that lactic acid gets produced inside those guys, how that lactic acid eventually is broken down in their bodies and what we can do with that substance [. . ] we count down. . 321

at this moment, the lactic acid is being produced inside those guys right now they are busy burning glucose that was inside their stomachs at a certain moment you get too little oxygen inside those arms and you get instead of the normal waste products. . . we will learn what they are later. . you get lactic acid

[to the two students] stay like this until you can't hold anymore [students lower their books] 1 minute 49 and 1 minute 53, that is really long

This introduction appears to have impressed the students. Indeed, in a repetition session in the final lesson, almost 3 months later, a student literally mentions this example as an answer to an open question. The teacher then extracts the general idea from this specific context.

$\mathrm{T}$ and now my question to you all is: how can you produce lactic acid?

$[\ldots]$ search in your notes and preferably in your memory $[. .$.

$\mathrm{S}$ for example, if you hold something heavy and keep standing still, then you get lack of oxygen in your muscles and you start producing lactic acid

$\mathrm{T}$ ok so how do you produce lactic acid.. . during exercise and you are very right about the lack of oxygen

Instructional Method Patterns We found lecturing to be the predominant instructional method. Most of the instruction was done in a teacher-directed way; student initiative hardly had any influence on the course of instruction. Student debate as a method of instruction did not show up in the selected video segments.

The in-depth analysis shows that students often seem eager to interact. Sometimes there is a beginning of interactive teaching, but the teacher tends to shift to lecturing.

$\mathrm{T}$ so the nucleus has a positive charge and the electron was negative my question to you is again: why doesn't the electron move towards the nucleus?

$\mathrm{S} 1$ it is more minus than plus

S2 there is much space

$\mathrm{T}$ there is much space

$\mathrm{S} 3$ there is also a neutron

$\mathrm{T}$ why does it keep racing [moves his arm] around it?

$\mathrm{S} 4$ maybe inside there is [inaudible]

S5 more electrons than protons

S6 the attracting force is just enough to let it spin around it and not pull it towards. .

$\mathrm{T}$ guys, I can combine the explanations that I've heard there it comes the electron indeed feels the positive nucleus that's why it stays close to it at the same time the electron has a high speed and that speed is so high that it keeps racing around it the 
speed is exactly right to keep spinning around the nucleus I will explain it by an example

Instructional Method and Lesson Content Patterns In the few places where interactive instruction took place, the nature of the content matter was conceptual (i.e., chemical concepts, theory). An interactive demo in the first lesson (video segment 1) is the only exception.

We have observed several times that apparent misconceptions were not elaborated. The following segment was taken from a lesson part about sodas and the dental erosion they cause. The teacher repeats his previous remark without addressing the student's misconception.

$\mathrm{T}$ those saccharides lead to damage to the enamel but especially those ACIDS cause it

$\mathrm{S}$ yes that reacts with. . in your teeth there is a minus $\mathrm{pH}$ and in your. . in coca cola there is plus and those react, or vice versa

$\mathrm{T}$ well you can say in chemistry terms that the acidity of coke is such that it does damage to your enamel

Control Patterns We observed that choices in the lessons were made by the teacher for about $90 \%$ of the time.

It appeared that student contributions of contexts such as examples from personal experiences or other sources ("I have heard that...") were admitted only briefly. The teacher responds either by ignoring (no follow-up) or cutting off and rounding up (see below), in both cases without elaborating in interaction with the students.

$\mathrm{S}$ I have also heard. . or read that if you drink cola or grapes or wine, it is better to eat some cheese or drink some milk. .

$\mathrm{T}$ [interrupting] that neutralizes. . .

$\mathrm{S}$ [continuing simultaneously] or rinse the mouth with milk that is also possible that's why the French don't have many cavities because they often eat cheese after dinner

$\mathrm{T}$ I didn't know that story, but I immediately believe it because it repairs the acid level in the mouth and therefore you indeed get a less severe attack on the teeth

Remarkably often, the teacher control did not address the Lesson content as such, but concerned students' cognitive learning activities. The following examples were taken from distinct lesson segment.

$\mathrm{T}$ I want to get all of you in the learning mode

$\mathrm{T}$ keep this schema inside your head

$\mathrm{T}$ carve out these sentences in your memory

$\mathrm{T}$ again search in your memory

$\mathrm{T}$ put an exclamation mark in the margin you'll get questions about this

Check Patterns Verifications of students' understanding were quite rare: 23 times in 4 hours of lesson time. Further analysis of the way the teacher checked students' understanding showed that the time between a check question and discussing the answer was often shorter than announced by the teacher. 
$\mathrm{T}$ write down the words 'acid' and 'base' and write down a few notions that have to do with acids and bases write down things you remember use your memory, use your classmates, use your notes, browse through the module [... ]

[cleans blackboard with wet cloth] we take as much time as it takes for the blackboard to dry well what do you still know about acids and bases I think this part of the lesson can go fast

I just said we'd wait until the blackboard is dry but we can also start to make an inventory

listen well to each other and write down keywords that you hear in each other's answers

I have seen four raised hands there's the first

$\mathrm{S}$ if you go from 7 to 8 then it is 10 times more anti-acid

$\mathrm{T}$ ok, so you have the $\mathrm{pH}$ scale yes ok and that $\mathrm{pH}$ scale works with steps of 10, a factor 10 does everybody remember?

Keeping track of the content of (guided or unguided) student work on the notes sheets revealed that the presented questions and assignments were not always followed up by the teacher after completion by the students, especially when the Lesson content was contextual of nature. This is comparable to our findings with respect to the teacher's response to students' initiatives (see the results on the item of Control).

In the case of check questions during instruction, we observe a similar tendency with respect to classroom interaction as we mentioned a few times already: instead of exploring students' understanding, the teacher usually formulates the answer himself, including the reasoning, without any discussion.

$\mathrm{T}$ now I have a problem for you and you have to think about it for a while, that's obvious

we have cola with $\mathrm{pH} 3$

I want to dilute that cola solution with water I add water what happens with the $\mathrm{pH}$ ?

$\mathrm{S}$ it gets lower

$\mathrm{T}$ does the pH get, three options, does it get higher does it get, like I just heard already, lower

or, third option, the pH does not change don't discuss it, I want you to think about it

S1 higher!

$\mathrm{T}$ so the value becomes, does it increase does it increase? does it proceed to 4, 5 or will it become 2 or 1 or does it stay 3

S2 higher!

$\mathrm{T}$ we will vote who says higher? [students raise hands] there are two who haven't raised their hands you. . . think it stays the same that it becomes lower, nobody believes that, right? because nobody believes the number of acid particles increases when I add water, yes? 
Check and Instructional Method Patterns The few check questions and assignments occurred mostly during instruction for students' work, and less during lecturing.

This concludes the description of the found patterns. These will be used to characterize the teacher's classroom practice (as a manifestation of his PCK-in-action) in terms of the underlying pedagogical elements M1 to M4 and their interrelationships, see Table 4. This will be done below, to compare the teacher's articulated PCK-on-action with his classroom practice, and in the Conclusion section to formulate an answer to Research Question 3.

\section{Results-Research Question 3}

In Table 6, we use the results of the interview and the results of the classroom observation (using Table 4 connecting pedagogical elements and interconnections with observational patterns) to compare the teacher's articulated PCK-on-action with his classroom practice. For each pedagogical element (M1 to M4) and found interconnection, we paraphrase the results of our respective earlier analyses in short sentences, in order to highlight relevant similarities and differences.

\section{Conclusion}

The research questions in this study were as follows.

1. How can the teacher's articulated PCK-on-action with respect to the module content be portrayed in terms of the underlying pedagogical elements M1 to M4 and their interconnections?

2. How can the teacher's classroom practice be described in the same terms?

3. How can the relation between the teacher's articulated PCK-on-action and the teacher's classroom practice be characterized in these terms?

\section{Conclusion-Research Question 1}

As to Question 1, we conclude that the teacher's knowledge about goals and objectives (M1) with respect to this module is very explicit and clearly reflects several aims of the contextbased approach to science education. However, the expressed goals are not specific: they are not articulated in terms of specific module concepts, themes, or contexts (see Table 1).

The expressed teaching strategy (M3) is elaborated and could be called constructivist, and is connected with his goals through explicit and coherent reasoning. The teacher's knowledge about students' understanding and motivation (M2) is restricted to the perceived difficulty of the subject matter, the alleged students' aversion towards connecting this subject matter to one type of context (i.e., personal life), and their preference for interactive learning. The latter aspect fits with the teacher's reasoning about instructional strategies. The expressed goals and objectives, however, are not aligned with the students' characteristics as described by the teacher. As to assessment (M4), the teacher appears to prefer the testing of conceptual content (via "lots of" check questions throughout instruction and a final summative test) and not to measure the students' ability to connect this content to relevant contexts. This shows that his knowledge about assessment does not match the expressed context-related learning objectives. The idea of conceptual check questions fits within the teacher's 
Table 6 Comparison between teacher's PCK-on-action and classroom practice

\begin{tabular}{|c|c|c|}
\hline & Teacher's articulated PCK-on-action & Teacher's classroom practice \\
\hline $\begin{array}{l}\text { Goals and } \\
\text { objectives } \\
\text { (M1) }\end{array}$ & $\begin{array}{l}\text { In this context-based module, the teacher } \\
\text { wants students to acknowledge the role of } \\
\text { chemistry in society, and to connect chem- } \\
\text { istry with personal life and society. } \\
\text { Moreover, they should learn to read science } \\
\text { articles. Finally, they should acquire lab } \\
\text { skills. }\end{array}$ & $\begin{array}{l}\text { In teaching the module, attitude was hardly } \\
\text { ever addressed. Moreover, conceptual } \\
\text { content prevailed in the lessons }(81 \%) \text {. } \\
\text { Personal contexts were addressed more } \\
\text { frequently than societal and technological } \\
\text { contexts. In general, contexts were not } \\
\text { embedded in concepts but rather addressed } \\
\text { after treatment of concepts. No } \\
\text { epistemologic content was observed. Note } \\
\text { that the recordings concerned the } \\
\text { classroom, not the lab. }\end{array}$ \\
\hline $\begin{array}{l}\text { Students' } \\
\text { understand- } \\
\text { ing (M2) }\end{array}$ & $\begin{array}{l}\text { The teacher thinks that students consider the } \\
\text { subject of the module as difficult. }\end{array}$ & $\begin{array}{l}\text { As indicated before, this element was not } \\
\text { observed directly. }\end{array}$ \\
\hline $\begin{array}{l}\text { Interconnection } \\
\text { M2-M1 }\end{array}$ & $\begin{array}{l}\text { The teacher believes the students have no a } \\
\text { priori interest in connecting chemistry to } \\
\text { personal life. However, he expects that they } \\
\text { are ready to use their acquired knowledge } \\
\text { and learn about real-life applications. }\end{array}$ & $\begin{array}{l}\text { Students' understanding was not observed } \\
\text { directly. However, the analysis of other } \\
\text { items brought up some aspects of the } \\
\text { students' attitudes. In particular, we } \\
\text { observed that students came up with own } \\
\text { examples of relevant personal life contexts. }\end{array}$ \\
\hline $\begin{array}{l}\text { Instructional } \\
\text { strategies } \\
\text { (M3) }\end{array}$ & $\begin{array}{l}\text { The teacher prefers a heuristic approach with } \\
\text { lots of interactions, in which he intends to } \\
\text { stimulate students to come up with } \\
\text { questions. }\end{array}$ & $\begin{array}{l}\text { In the observations, lecturing appears to be the } \\
\text { predominant instructional method. Teacher } \\
\text { control was observed in } 90 \% \text { of the } \\
\text { observation intervals. Students' learning } \\
\text { activities were often initiated and regulated } \\
\text { by the teacher. Interactive instruction on } \\
\text { conceptual content was frequently taken } \\
\text { over by the teacher. Students' context } \\
\text { contributions (mostly regarding their } \\
\text { personal lives) tended to be ignored or cut } \\
\text { off. }\end{array}$ \\
\hline $\begin{array}{l}\text { Interconnection } \\
\text { M3-M1 }\end{array}$ & $\begin{array}{l}\text { In order to reach the learning goals, the } \\
\text { teacher prefers to first connect to students' } \\
\text { daily life, then introduce chemical facts, } \\
\text { then show value, or rather letting students } \\
\text { to discover this. }\end{array}$ & $\begin{array}{l}\text { In the lessons we did not observe any student } \\
\text { discussions. There was hardly any } \\
\text { elaboration of students' misconceptions. } \\
\text { Interaction was seen mostly in combination } \\
\text { with conceptual content. }\end{array}$ \\
\hline $\begin{array}{l}\text { Interconnection } \\
\quad \text { M3-M2 }\end{array}$ & $\begin{array}{l}\text { With respect to the chosen teaching approach, } \\
\text { the teacher asserts that his students enjoy } \\
\text { interaction with the teacher and with other } \\
\text { students. }\end{array}$ & $\begin{array}{l}\text { Again, students' understanding was not } \\
\text { observed directly. However, analysis of } \\
\text { other items shows that students appear } \\
\text { eager to interact. }\end{array}$ \\
\hline $\begin{array}{l}\text { Assessment } \\
\text { (M4) }\end{array}$ & $\begin{array}{l}\text { The teacher prefers to monitor students' } \\
\text { understanding by check questions. }\end{array}$ & $\begin{array}{l}\text { In the lessons of the module, very few check } \\
\text { questions were found. Moreover, the } \\
\text { teacher allowed little time for students' } \\
\text { thinking; answers were often given by } \\
\text { himself. }\end{array}$ \\
\hline $\begin{array}{l}\text { Interconnection } \\
\quad \text { M4-M1 }\end{array}$ & $\begin{array}{l}\text { The teacher favors the conceptual content of } \\
\text { the module to be assessed by a final test. } \\
\text { He rejects explicitly assessing the students' } \\
\text { ability to connect chemistry with personal } \\
\text { life. }\end{array}$ & $\begin{array}{l}\text { Indeed, no checks regarding this connection } \\
\text { were observed. }\end{array}$ \\
\hline $\begin{array}{l}\text { Interconnection } \\
\quad \text { M4-M3 }\end{array}$ & $\begin{array}{l}\text { The teacher prefers to apply check questions } \\
\text { throughout the lessons. }\end{array}$ & $\begin{array}{l}\text { Check questions did not come up often, and } \\
\text { mainly occurred during lecturing. }\end{array}$ \\
\hline
\end{tabular}

preferred interactive instruction, and is explicitly connected (by the teacher's reasoning) with several aspects of the perceived students' preferences and needs. 
Fig. 3 Extent and coherence of the teacher's PCK

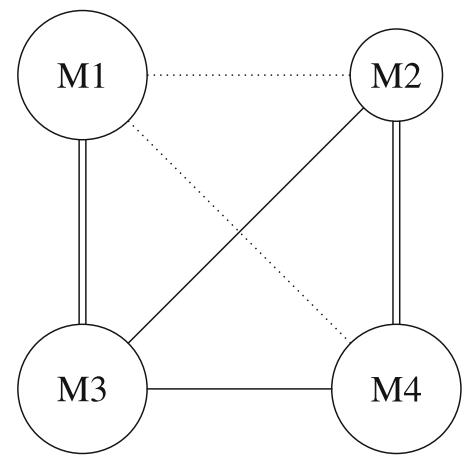

The features of the teacher's PCK-on-action are visualized in Fig. 3. The sizes of the circles indicate (relative) extent of the respective PCK elements. The connecting lines indicate interconnectedness, from weak or absent (dotted lines) to strong (double lines). None of the representations of the knowledge elements is rich (in the sense that they do not contain specific content), and M2 is even poor (i.e., also restricted). Moreover, the knowledge elements are not fully interconnected. Hence we must conclude that the PCK-on-action is not rich and not coherent, and thus not strong (see the "Introduction" section).

\section{Conclusion-Research Question 2}

With respect to Question 2, we found the observed learning goals and objectives (M1, in the form of lesson content) to be largely conceptual. Contexts, if used, were employed as direct applications or illustrations of chemical concepts in personal life and society.

Lecturing was the predominant observed instructional strategy (M3). This leads to a traditional combination of teacher-directed education for learning chemical concepts. The teacher persists in a lecturing style in the rare cases where conceptual content is combined with relevant contexts. On the other hand, moments of interactive teaching only occurred in connection with abstract conceptual goals and objectives. In addition, our analysis showed the strong and persistent dominance of the teacher, although students appeared eager to take initiative. The teacher even initiated the regulation of the students' mental activities.

The teacher elaborated only scarcely on students' ideas, and missed evident misconceptions. Although students' understanding (M2) was not observed directly, we must conclude that the observed instructional strategy seems not to be connected with students' manifestation in class.

Check questions or other types of formative assessment (M4) were rare, and occurred mainly during lecturing and addressed abstract conceptual content. Again, we see that a constructivist style is connected to a more traditional choice in other elements.

We conclude that the observed practice can be typified as traditional science education around conceptual knowledge, chemistry theory. The teacher's actions in the classroom were little varied and quite consistent, that is, in all aspects of the lessons, classroom interactions were dominated by the teacher with little room for student input or autonomy (teacher-directed education).

\section{Conclusion-Research Question 3}

Question 3 concerns the overall relation between the teacher's articulated PCK-on-action and his classroom actions. For each pedagogical element and each combination of these, we use 
the comparison part of the Results section to characterize whether there is a similarity or difference between PCK-on-action and practice.

On the whole, there is little correspondence between the teacher's PCK-on-action and his classroom actions with respect to goals and objectives (M1), instructional strategies (M3), and assessment (M4). In these cases, the articulated PCK-on-action appears to be more constructivist than his teaching practice.

We will now focus on the interconnections between pedagogical elements.

First, the foreseen attitudes of students towards the articulated goals and objectives were not found in practice (Interconnection M2-M1). On the contrary, students seemed eager to learn about the role of chemistry in their personal lives, contrary to the teachers' expectations.

Moreover, the teacher's intended alignment between learning goals and instructional strategies did not correspond to the observed actions (Interconnection M3-M1). Indeed, for teaching about the role of chemistry concepts in real life, the teacher rarely employs the interactive, discovery-oriented approach that was found in his articulated PCK-on-action.

Furthermore, the articulated alignment of instructional strategies with students' attitudes is not seen in practice (Interconnection M3-M2). Although the students appeared eager to interact with the teacher, the classroom interactions were dominated by the teacher.

Then, with respect to the teacher's choices for assessing specific learning goals, the observed practice is consistent with the teacher's articulated PCK-on-action (Interconnection M4-M1). Indeed, no checks regarding the relation between chemistry concepts and real-life contexts were observed.

Finally, the anticipated embedded assessment throughout the instruction was not observed in practice (Interconnection M4-M3).

Summarizing, the relationship between the teacher's PCK-on-action and the teacher's actions in practice is weak in the cases of single pedagogical elements, as well as for four out of five interconnections.

\section{Discussion}

With this case study we intended to contribute to theories on science teachers' PCK as well as to methodologies for investigating this complex construct (see the rationale in the Aim of the Study section). Moreover, we wanted to make a contribution to the current debate on PCK and its development.

To complement previous large-scale studies on the relation between teacher PCK and teacher action, we compared a teacher's articulated PCK-on-action with his classroom practice (as a manifestation of his PCK-in-action). In the process of our in-depth investigation, we explored an alternative way to investigate classroom practice and its relationship with PCK-on-action.

Below, we reflect on the findings regarding the research questions. Then we will reflect on the methodology, in particular the limitations of the present study, other quality aspects of the method, and the way we applied the observation table to investigate classroom practice. Finally, we will discuss the implications for the concept of PCK and PCK research in a broader sense.

\section{Reflection on the Research Findings}

In this reflection, we will attempt to interpret the results and conclusions of our case study. Our reflections will be organized according to the research questions. 
Reflection-Research Question 1 Regarding our findings on the teacher's PCK-onaction, it is remarkable that the PCK elements M1, M3, and M4 are generic rather than topic-specific. What the teacher expresses here might be a more general wish or ideal concerning learning goals, instructional strategies, and assessment in context-based education, instead of insights drawn from experimentation in teaching this specific module. We may even hypothesize that little or no PCK development has taken place yet. This is supported by the restricted size of PCK element M2, which is often associated with a beginning or weak PCK. Besides, the connection of M2 with M1 and M3 is limited, which means that the teacher's pedagogical reasoning is incomplete.

Reflection-Research Question 2 Regarding the observed practice, we found little alignment with the context-based approach to science teaching and learning. Innovative activities related to M3 or M4 (interactive teaching and formative assessment, respectively) only occurred in combination with traditional conceptual learning goals (M1). It looks like the teacher is innovating step by step.

Reflection-Research Question 3 We will look at the findings with respect to the comparison of the teacher's PCK-on-action and his classroom practice from three theoretical perspectives: first, from a cognitive-constructivist view on teacher knowledge as a predictor of teacher practice; second, from the perspective of decision making as an explaining mechanism connecting the two; and third, from the perspective of inhibiting psychological factors as explanations for the observed gap between teacher knowledge and practice.

Teacher Knowledge Versus Teacher Practice The starting point of our research was the cognitive-constructivist point of view that teacher knowledge (i.e., PCK) is built upon prior knowledge (and beliefs) from different domains, and upon experiences from practice, including interactions with students and colleagues (cf. Clarke and Hollingsworth 2002), and that teacher knowledge is an important determinant of teacher activities (Shulman 1986, 1987). In this view, there is a supposed reciprocity between a teacher's PCK-onaction and his behavior in the classroom, see the "Introduction" section.

The observed differences between the teacher's PCK-on-action and the teacher's practice may be explained by the idea that his knowledge with respect to teaching and learning in the new context-based lesson module is not "strong" enough yet to "stimulate [substantial] change in practice" (Park and Chen 2012, p. 939). From a cognitive-constructivist point of view, new experiences in practice might change teacher's knowledge, gradually. To make further progress, it would make sense to carefully analyze the lesson module on Lactic Acid with respect to the aims and characteristics of context-based education. It might be helpful to apply high quality teaching materials in which those aims are realized in a transparent and attractive way (Henze et al. 2007).

Teacher Decision Making As was discussed in the Introduction section, teachers' classroom actions are informed by their PCK-on-action, but are also a result of decision making on the spot, and hence involve a dynamic kind of knowledge which is referred to as PCK-inaction (Park and Oliver 2008). With this in mind, one might expect to find some degree of difference between a teacher's PCK-on-action and his classroom practice. This difference is known in educational literature as the problem of enactment (cf. Kennedy 1999). The extent 
of the difference in our case, however, is remarkable, and the question arises how this can be interpreted.

Below, we will explore aspects of the decision making process in the context of our case study. The exploration will be based on literature, the results and conclusions of our study, and reflections of our teacher.

Decision making appears to be influenced by both personal factors (such as beliefs and values) and situational factors, see Fig. 4 (Bishop and Whitfield 1972). Some elements of the model are related to teachers' knowledge (i.e., PCK-on-action), in particular Background and Experience and Aims and Objectives. We will focus on the elements Beliefs and Values and Teaching Situation.

As to the teacher's beliefs, we recall the relatively high score on curriculum emphasis Fundamental Chemistry ( 3.75 on a scale of 5) besides the predominant Chemistry, Technology and Society emphasis score (4.0). From this, we can speculate that it is tempting for the teacher to decide (triggered by a specific situation) to turn to a more traditional and established instructional strategy. The fact that such a traditional strategy was not found in the teacher's PCK-on-action could be explained by the idea that his CTS emphasis was predominant by absence of this specific teaching situation.

In his reflection on the findings of our study, the teacher addressed such specific teaching situations that occurred during teaching of the module on lactic acid. He mentioned, for instance, that the level of the students had been considerably lower than in previous implementations of the module. He acknowledged that the match between the instructional method and the level of the students was not well-considered in his CoRe and needs to be improved.

In the communicative approach framework by Mortimer and Scott (2003), the teacher's dominant behavior can be characterized as "authoritative." Such an authoritative approach can be appropriate in case a teacher wants to resolve issues brought up by students. In this way, the communicative approach reflects the normative side of science as "an authoritative discourse which offers a structured view of the world” (Scott et al. 2006, p. 622). The teacher, however, suggested that his dominant teacher behavior could be explained by his feeling that during classroom instruction the students were not as responsive and involved as he had hoped. He also complained about lack of time because a physics colleague asked him to devote some class hours to the topic of atom models. However, the teacher now realized that it could have been the other way around, namely that his own teaching behavior could have been a determinant for the students' lack of response. He started to wonder whether the observed one-sidedness in the teacher-student interaction had been in fact a response to stress (due to time pressure or high workload), and if so, whether this response is permanent or not.

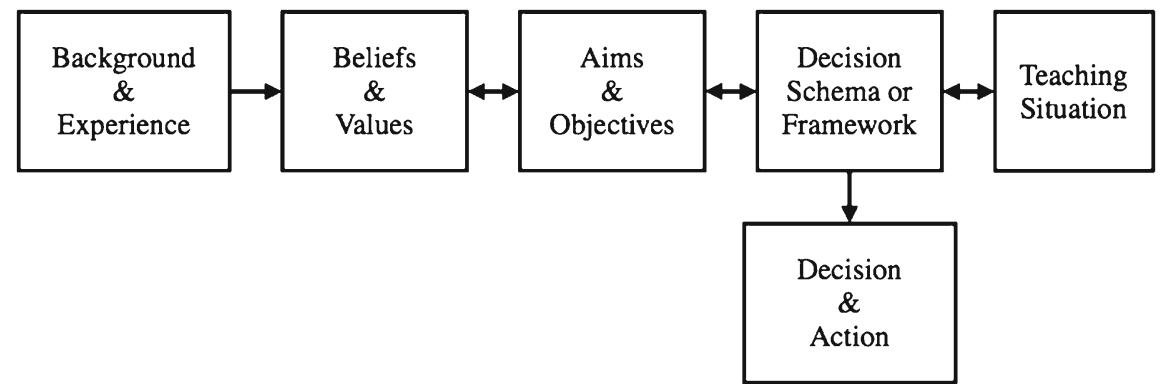

Fig. 4 Decision making framework (Bishop and Whitfield 1972), adapted by Borko et al. (2008) 
Psychological Factors The decision making framework by Bishop and Whitfield (1972) focuses on (unconscious) rational aspects. As we perceive teacher knowledge as a part of the whole of teacher cognition in a broad sense, there are also other psychological factors that might play a role and form an explanation for the gap between the teacher's articulated PCK-on-action and his actions in the classroom. Based on research in organizational psychology, Pfeffer and Sutton (2013) have identified a number of key factors that contribute to the knowing-doing gap, that is, the discrepancy between people's intentions and their actual behavior, including inhibitions by fear, taboos that prevent and forbid action, lack of structure for action, and personal items predisposing from taking action.

In the case of our teacher, fearing loss of control could be an inhibiting factor. Changing to constructivist education is difficult for some teachers. In particular, the loss of control can be threatening. Even teachers claiming to support constructivist innovations are sometimes affected by this factor in practice. Traditionally, teachers are instructed that the mark of a good teacher is that the teacher is in control of the class (Taylor 1987). Indeed, our teacher might have such a traditional underlying (but concealed) orientation towards teaching science (Friedrichsen et al. 2011; Magnusson et al. 1999). Moreover, he could have reasoned that giving away control might lead to students missing important topics (i.e., traditional concepts from themes I, III) and thus failing in the final test. In case the teacher believes he will be held accountable for this, he might have felt forced to direct all classroom activities instead of letting the students find their own ways. This would fit closely to the taboo “don’t risk making a mistake" preventing action (Pfeffer and Sutton 2013).

Reflection on teaching practice is regarded as a crucial factor for developing personal knowledge and beliefs (Clarke and Hollingsworth 2002; Schön 1983; Wongsopawiro 2012). Although the teacher mentioned reflection in the initial interview, he did not indicate any structured method (e.g., Korthagen and Kessels 1999). This could point to another key factor identified by Pfeffer and Sutton (2013), namely lack of a structure to reflect upon the outcomes of action ("learning from mistakes").

The teacher's stress response mentioned earlier, with the question whether this is structural or not, could be a personal item predisposing from taking action in the sense of Pfeffer and Sutton (2013).

The teacher's reflection on our findings was immediate but appears somewhat superficial. It will be interesting to investigate whether a stimulated recall technique could help discovering other factors, for example lack of structure for action, that is, teaching skills.

\section{Reflection on the Research Methodology}

Limitations of the Study In order to elicit the teacher's PCK-on-action, we interviewed the teacher using the CoRe instrument. However, when applying a well-established instrument like the $\mathrm{CoRe}$ form, teachers are not always able to verbalize their professional knowledge. Moreover, one single instrument (i.e., CoRe) cannot capture the full complexity of a teacher's knowledge (Kagan 1990). In addition to the elicitation of PCK in spoken form, alternative sources can be considered, including teacher concept maps (cf. Meijer et al. 1999) and repertory grids (cf. Henze et al. 2007).

We have only partly studied the lesson recordings (namely those 240 min that met our requirements for observation analysis). Moreover, we can only speculate about the 
teacher's thoughts and backgrounds of his behavior. Therefore we informed the teacher about the differences we noted between the observations and his PCK articulation, to seek confirmation.

The teacher said he found our findings "rather confronting." On the other hand, he told us that he recognized the main patterns we found in our observations. He admitted he had not been conscious of them before and immediately started exploring possible explanations. This reaction suggests that our findings were accurate and relevant.

Quality Aspects of the Study Below, we will discuss methodological aspects of our study related to the framework of Lincoln and Guba (1985). Supporting the credibility of the research is the "prolonged engagement" (Lincoln and Guba 1985) of the researchers. Our teacher was a member of a group followed extensively by one of the authors (a chemist and former chemistry teacher) in the context of the contextbased curriculum reform. Furthermore, both authors achieved a broader overview of the teaching of this particular lesson module by studying other data sources such as students' work, as part of the bigger project mentioned in the Introduction. Also, our application of respondent validation ("member checking"), both formally, with respect to data $(\mathrm{CoRe})$, and informally, with respect to findings (correspondence between the teacher's PCK-on-action and his classroom practice), contributes to credibility. Adding triangulation could be a way to further enhance credibility in follow-up studies (Kagan 1990).

We have done our best to provide a multifaceted "thick" description of the research setting, including the structure of the lesson module, the educational reform, and the teacher's background and curricular beliefs, thus providing information to assess the transferability of the results to a particular context.

The construction of the observation table involved completing the table for sample video segments independently by both researchers, discussing differences, and adjusting the category descriptions, to contribute to the dependability of the research. Indeed, we have reached a strong consensus with respect to the video recordings. The same holds for the analytic coding of the teacher's CoRe. We plan to further develop our research method to establish proper validity and reliability.

Finally, the availability of recordings, codings, and notes sheets contributes to the confirmability of the research.

Application of the Observation Table To investigate the teacher's practice, we constructed a descriptive observation table. With this table we were able to capture all the actions of the teacher during the execution of the lesson module. Moreover, the table provided a way to discover patterns within and between observational items. The proven applicability in our case suggests that the choice of observation items and observation categories is suitable for a wider range of situations. The observation table can also play a role in systematic reflection by teachers on their classroom practice, sharpening and adjusting their PCK, and thus fostering their PCK development. Moreover, we envisage that the procedure of discovering patterns could provide additional input for stimulated recall interviews, which currently mainly rely on single events or incidents.

The analytical framework of Fig. 1 turned out to be a successful way to unravel and compare teacher PCK-on-action and teacher practice. Indeed, we were able to decompose both PCK and classroom actions into components of a feasible level of complexity. 


\section{Contribution to PCK Research}

Our study contributes to research on teacher knowledge and its development. Our findings give more insight into possible mechanisms relating teacher PCK-on-action with classroom practice. The unraveling of these in terms of pedagogical elements M1 to M4 and their interconnections provides a useful basis for in-depth research on this relation, thus complementing existing more large-scale studies. In particular, the observation table can be applied for analyzing classroom practice as primary data source, and hence gives an additional possibility besides using it as secondary source in stimulated recall interviews.

This study specifically contributes to research on context-based science education. Our detailed analysis, distinguishing between conceptual and contextual content, was able to reveal gaps in the teacher's pedagogical reasoning. Moreover, our in-depth analysis made it possible to note the "step by step" development of the teacher's PCK. Finally, our findings helped reflecting on the influence of beliefs and orientations on the execution of context-based science programs, in which students' attitudes and constructivist teaching strategies are important factors.

In the context of the study, the lesson module on lactic acid appears in two roles. First, from the cognitivist-constructivist perspective, it can be viewed as an external source for our teacher's PCK development (cf. Henze et al. 2007). At the same time, the teacher is one of the authors of the module, so we can expect that it also contains aspects of his PCK-on-action. This fits to a recent socio-cultural and situative perspective (Lave and Wenger 1991), in which teacher knowledge is assumed to be integrally and inherently situated in the everyday world of teachers. Moreover, this knowledge is seen as not only residing in the individual, but distributed among people and their environments, including the objects, books, tools, and the communities of which they are a part (Greeno et al. 1996). In this view, PCK is defined as a multifaceted concept, that is, not only encompassing knowledge but also practice, and even artifacts by teachers and students. This leads to the suggestion to analyze the lesson module in terms of the four pedagogical elements, not only as a source for the teacher's PCK-on-action, but also as an artifact containing aspects of this.

The above reflections contribute to the current debate on the nature of the construct of PCK (Berry et al. 2015). As part of this debate, an integrated model of teacher professional knowledge and skill including PCK (Gess-Newsome 2015) was conceived at the PCK Summit held in 2012 in Colorado, USA (BSCS 2013). As to this model, our study can be situated in the specific component of Classroom practice. (Gess-Newsome 2015) including knowledge, skill, and enactment on one side, and classroom context on the other. Indeed, the focus of our study is the relation between knowledge (covering both PCK-on-action and PCK-in-action) and its enactment.

The model also contains a component Amplifiers and filters, that is, factors moderating the transfer of more collective Topic-specific professional knowledge to Classroom practice. These amplifiers and filters include teacher beliefs and orientations, prior knowledge, and context.

Our discussion of the decision making mechanism suggests that such amplifiers and filters also play a role within the Classroom practice component, namely by moderating the relation between knowledge and enactment. Besides beliefs and orientations from Bishop and Whitfield (1972), also psychological factors (Pfeffer and Sutton 2013) seem to act as moderators. In this way, our research could contribute to further refinement of the integrated model, thus stimulating further in-depth research on teacher knowledge and classroom practice, with as ultimate goal the enhancement of students' learning. 


\section{Appendix A: Classroom Observation}

\section{Observation Table}

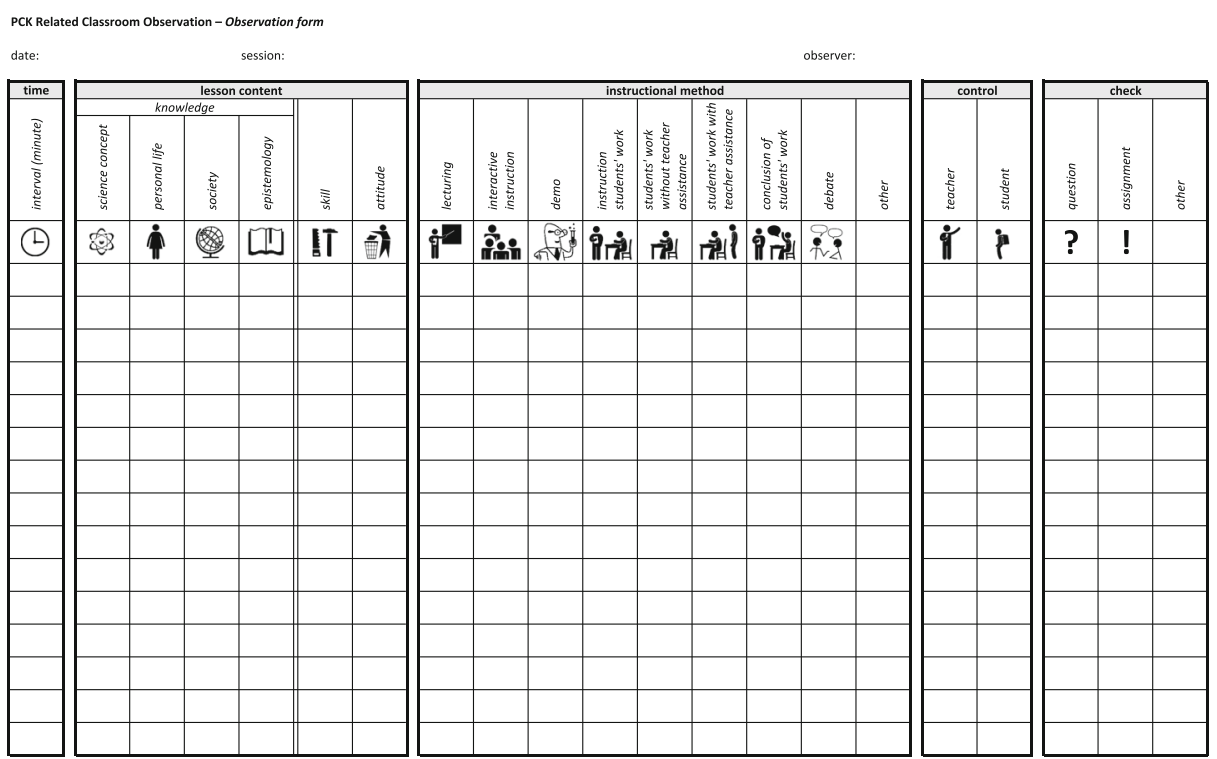

\section{Notes Sheet}

PCK Related Classroom Observation - Notes sheet

date: session: observer:

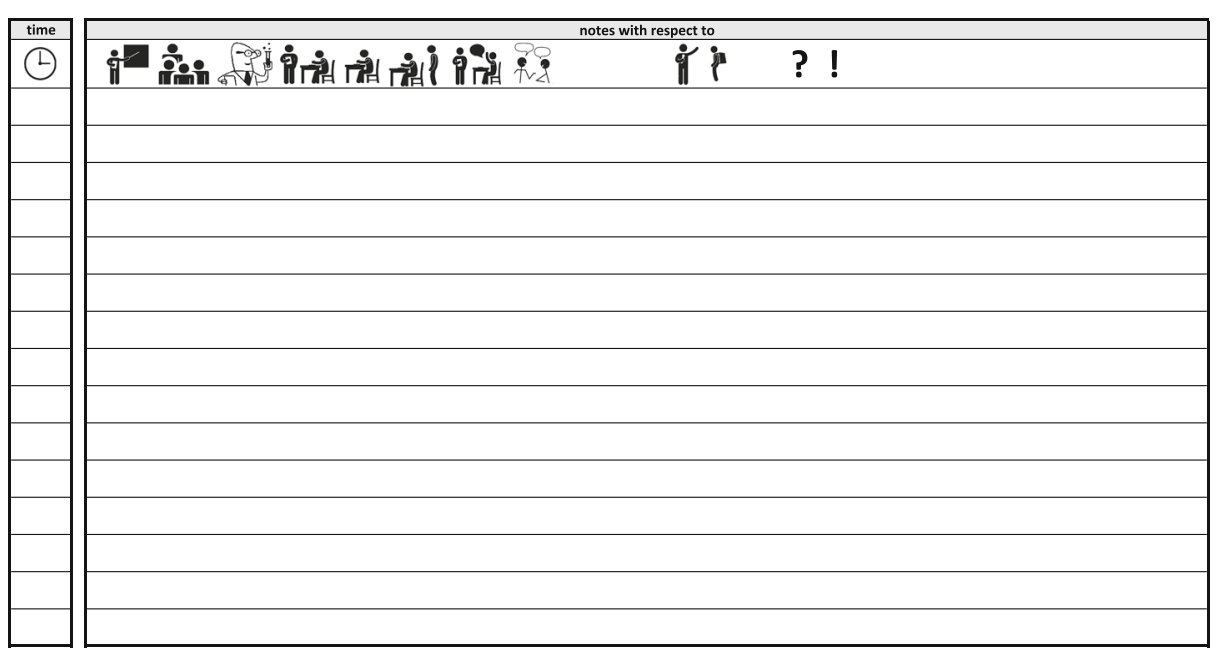




\section{Observation Guide}

\section{Lesson Content}

What is the lesson about? What is the topic of this part of the lesson? Usually this topic will be related to the learning objectives of the lesson segment. We distinguish three categories.

Knowledge This is about cognitive aspects. We distinguish different points of view.

- Science concepts: the (scientific) theory

Examples: the way the human heart works, acids and bases, exponential functions, light breaking through a lens

- Personal life: topics from the personal environment that have scientific aspects

Examples: the effects of smoking on the human heart, lactic acid production in the muscles, bacterial growth in infections, compensation of short-sightedness with glasses

- Society: topics from society that have scientific aspects

Examples: banning smoking in public spaces, bioplastics (poly lactic acid), demography, $3 D-t v$

- Epistemology: nature and origin of scientific knowledge

Examples: research on heart diseases, history of the periodic table of elements the influence of World War II on the development of cryptography, deduction of breaking laws from properties of light.

Skill This is about physical (motoric) actions.

Examples: construction of microscope preparates, titration, constructions with compasses and ruler, realizing electrical circuits.

N.B. Cognitive (mental) skills belong to the category Knowledge. Examples: calculating something, balancing a chemical reaction equation.

Attitude This concerns attitudes and opinions with respect to (parts of) the discipline or decisions and reasoning with respect to societal matters connected to the discipline.

Examples: admissibility of genetic manipulation, sustainable production, the importance of precise proofs, yes or no to nuclear energy

\section{Instructional Methods}

This concerns the contribution of the teacher in the instruction. We distinguish 9 categories. We assume that only one category is in order at the same time. (Of course several categories can be present in a single observation interval.) 
Lecturing Plenary instruction by the teacher. Some interaction can be present, like a lecture in which the teacher asks questions every now and then (example: What is the result of this calculation?); the teacher, however, determines the course of the instruction. The teacher can use technical support materials such as powerpoint and smart board.

Interactive Instruction A structured interaction in which the teacher and the students together reach certain knowledge and understanding. The teacher leads the conversation. The role of the teacher differs from that in lecturing: he can promote questions to other students, and students can ask questions.

Demo The teacher supports the instruction by visualizing knowledge or having a skill demonstrated. The teacher can apply technical support, such as a video or applet.

Examples: illustration of the way the heart works through a computer animation; demonstration of a chemical reaction in a test tube; drawing an ellipse with a pencil, two nails and a piece of rope; visualizing light breaking in a lens; demonstrating preparate construction; demonstrating a titration; demonstrating measurement of an angle; demonstrating the calibration of an instrument.

Instruction for Students' Work The teacher ensures that the students know what they have to do and sets them to work (as part of the lesson).

N.B. Write down the assignment on the notes sheet.

Students' Work Without Teacher Assistance The teacher lets the students work by themselves; he does not assist and does not answer any questions.

Students' Work with Teacher Assistance The teacher supports the student while they work on an assignment, for example by asking questions, by giving feedback or by being available.

Conclusion of Students' Work Under supervision of the teacher, students' work (assignment, homework) is finished. This may involve displaying the results (product) or process.

N.B. Possible subsequent discussion of the contents is classified as lecturing or interactive instruction, depending on the instructional method.

N.B. Write down on the notes sheet which assignment is concluded (with a reference to the interval in which the instruction for students' work took place).

Debate The teacher leads a plenary discussion or debate, in which (various or opposed) opinions on a subject or question are exchanged.

N.B. This category is not to be mistaken for interactive instruction, or vice versa.

Other Activities that do not fit in the other categories, such as: a game, field work.

N.B. Write down the activity on the notes sheet.

Teacher The teacher takes the initiative with respect to content or instructional method. 
Student The student takes the initiative with respect to content (examples: Miss, could you explain this again? Sir, is this a good example? Exercise 3, please) or the instructional method (example: Miss, shall we do a nice lab session today?).

N.B. Write down the initiative on the notes sheet.

\section{Check}

In this item we keep track of the way the teacher verifies the learning outcome with respect to knowledge, skills or attitudes.

N.B. Write down the question or assignment on the notes sheet.

Question The teacher asks a question to the students.

Examples: Have you heard about obesitas? Do you remember what impulse moment is? Do you think production of poly lactic acid is a good example of condensation polymerization?

Assignment The teacher gives the students an assignment.

Examples: Calculate the speed of this cyclist. Write down in your own words what is the difference between temperature and heat.

Open Access This article is distributed under the terms of the Creative Commons Attribution 4.0 International License (http://creativecommons.org/licenses/by/4.0/), which permits unrestricted use, distribution, and reproduction in any medium, provided you give appropriate credit to the original author(s) and the source, provide a link to the Creative Commons license, and indicate if changes were made.

\section{References}

American Association for the Advancement of Science. (1993). Benchmarks for science literacy. Oxford.

Ball, D. L., Thames, M. H., \& Phelps, G. (2008). Content knowledge for teaching: what makes it special? Journal of Teacher Education, 59(5), 389-407.

Barendsen, E., \& Henze, I. (2015). Teacher knowledge and student attitudes in context-based science education. (Paper presented at NARST 2015, Chicago, IL)

Baumert, J., Kunter, M., Blum, W., Brunner, M., Voss, T., Jordan, A., et al. (2010). Teachers' mathematical knowledge, cognitive activation in the classroom, and student progress. American Educational Research Journal, 47(1), 133.

Bennett, J., \& Holman, J. (2002). Context-based approaches to the teaching of chemistry: what are they and what are their effects? In J. K. Gilbert, O. De Jong, R. Justi, D. F. Treagust, \& J. H. Van Driel (Eds.), Chemical education: towards research-based practice (pp. 165-184). Dordrecht: Kluwer.

Berry, A., Friedrichsen, P., \& Loughran, J. (Eds.). (2015). Re-examining pedagogical content knowledge in science education. New York.

Bishop, A. J., \& Whitfield, R. C. (1972). Situations in teaching. New York.

Bloom, B. S. (1956). Taxonomy of educational objectives: the classification of educational goals. Harlow, Essex: Longman Group.

Borko, H., Roberts, S. A., \& Shavelson, R. (2008). Teachers' decision making: from Alan J. Bishop to today. In P. Clarkson \& N. Presmeg (Eds.), Critical issues in mathematics education (pp. 37-67). Berlin.

Brown, S., \& McIntyre, D. (1993). Making sense of teaching. Buckingham: Open University Press.

Bruning, L., \& Michels, B. (2013). Concept-context venster: Zicht op de wisselwerking tussen concepten en contexten in het bèta-onderwijs. Enschede: SLO.

BSCS. (2013). PCK Summit. (Retrieved March 2015 from http://pcksummit.bscs.org) 
Clark, C., \& Peterson, P. (1986). Teachers' thought processes. In M. Wittrock (Ed.), Handbook of research on teaching (pp. 255-296). New York: Macmillan.

Clarke, D., \& Hollingsworth, H. (2002). Elaborating a model of teacher professional growth. Teaching and Teacher Education, 18(8), 947-967.

Cochran, F. K., DeRuiter, J. A., \& King, R. A. (1993). Pedagogical content knowing: an integrative model for teacher preparation. Journal of Teacher Education, 44(4), 263-272.

Coenders, F. (2010). Teachers' professional growth during the development and class enactment of context-based chemistry student learning material. In Unpublished doctoral dissertation. The Netherlands: University of Twente.

De Jong, O., Van Driel, J. H., \& Verloop, N. (2005). Preservice teachers' pedagogical content knowledge of using particle models in teaching chemistry. Journal of Research in Science Teaching, 42(8), 947-964.

Doyle, W. (1990). Themes in teacher education research. In Handbook of research on teacher education (pp. 324). New York: Macmillan.

Fenstermacher, G. D. (1994). The knower and the known: the nature of knowledge in research on teaching. Review of Research in Education, 20, 3-56.

Fischer, H. E., Borowski, A., \& Tepner, O. (2012). Professional knowledge of science teachers. In: Second international handbook of science education (pp. 435-448). Springer.

Friedrichsen, P. J., Abell, S. K., Pareja, E. M., Brown, P. L., Lankford, D. M., \& Volkmann, M. J. (2009). Does teaching experience matter? Examining biology teachers' prior knowledge for teaching in an alternative certification program. Journal of Research in Science Teaching, 46(4), 357-383.

Friedrichsen, P. J., Van Driel, J. H., \& Abell, S. K. (2011). Taking a closer look at science teaching orientations. Science Education, 95(2), 358-376.

Gess-Newsome, J. (1999). Pedagogical content knowledge: an introduction and orientation. In J. GessNewsome \& N. G. Lederman (Eds.), Examining pedagogical content knowledge (pp. 3-17). Dordrecht: Kluwer.

Gess-Newsome, J. (2015). A model of teacher professional knowledge and skill including PCK. In: A. Berry, P. Friedrichsen, \& J. Loughran (Eds.), Re-examining pedagogical content knowledge in science education (pp. 28-42). New York.

Gess-Newsome, J., Cardenas, S., Austin, B., Carlson, J., Gardner, A., Stuhlsatz, M.,. .. Wilson, C. (2011). Impact of educative materials and transformative professional development on teachers' PCK, practice, and student achievement. (Paper set presented at the Annual Meeting of the National Association for Research in Science Teaching, Orlando, FL)

Gibbs, G. R. (2007). Analysing qualitative data. Sage.

Gilbert, J. K. (2006). On the nature of 'context' in chemical education. International Journal of Science Education, 28(9), 957-976.

Gilbert, J. K., Bulte, A. M. W., \& Pilot, A. (2011). Concept development and transfer in context-based science education. International Journal of Science Education, 33(6), 817-837.

Greeno, J. G., Collins, A. M., \& Resnick, L. B. (1996). Cognition and learning. In D. C. Berliner \& R. C. Calfree (Eds.), Handbook of educational psychology (pp. 15-46). New York: Macmillan.

Henze, I., \& Barendsen, E. (2013). Teacher knowledge versus student learning in context based chemistry education: PCK-related analyses of student data. (Paper presented at NARST 2013, Puerto Rico)

Henze, I., Van Driel, J., \& Verloop, N. (2007). The change of science teachers personal knowledge about teaching models and modelling in the context of science education reform. International Journal of Science Education, 29(15), 1819-1846.

Henze, I., Van Driel, J. H., \& Verloop, N. (2008). Development of experienced science teachers' pedagogical content knowledge of models of the solar system and the universe. International Journal of Science Education, 30(10), 1321-1342.

Hodson, D. (1992). Assessment of practical work. Science \& Education, 1(2), 115-144.

Hoyle, E., \& John, P. D. (1995). Professional knowledge and professional practice. London: Cassell.

Kagan, D. M. (1990). Ways of evaluating teacher cognition: inferences concerning the goldilocks principle. Review of Educational Research, 60(3), 419-469.

Kennedy, M. M. (1999). The role of preservice teacher education. In L. Darlin-Hammond \& G. Sykes (Eds.), Teaching as the learning profession: Handbook of policy and practice, (pp. 54-86). San Francisco: Jossey Bass.

Korthagen, F. A. J., \& Kessels, J. P. A. M. (1999). Linking theory and practice: changing the pedagogy of teacher education. Educational Researcher, 28(4), 4-17.

Lave, J., \& Wenger, E. (1991). Situated learning: legitimate peripheral participation. Cambridge: Cambridge University Press.

Lincoln, Y. S., \& Guba, E. G. (1985). Naturalistic inquiry. Beverly Hills. 
Loughran, J., Mulhall, P., \& Berry, A. (2004). In search of pedagogical content knowledge in science: developing ways of articulating and documenting professional practice. Journal of Research in Science Teaching, 41(4), 370-391.

Magnusson, S., Krajcik, J., \& Borko, H. (1999). Nature, sources, and development of pedagogical content knowledge for science teaching. In J. Gess-Newsome \& N. G. Lederman (Eds.), Examining pedagogical content knowledge (pp. 95-132). Dordrecht: Kluwer.

Mayer, R. E. (2002). Rote versus meaningful learning. Theory Into Practice, 41(4), 226-232.

Meijer, P. C., Verloop, N., \& Beijaard, D. (1999). Exploring language teachers practical knowledge about teaching reading comprehension. Teaching and Teacher Education, 15(1), 59-84.

Mortimer, E., \& Scott, P. (2003). Meaning making in secondary science classrooms. UK: McGraw-Hill Education.

National Research Council. (1996). National science education standards. Washington, DC.

Nilsson, P., \& Loughran, J. (2012). Exploring the development of pre-service science elementary teachers $\hat{A} \breve{S}$ pedagogical content knowledge. Journal of Science Teacher Education, 23(7), 699-721.

Ogborn, J. (1997). Constructivist metaphors of learning science. Science \& Education, 6(1-2), 121-133.

Padilla, K., Ponce-de León, A. M., Rembado, F. M., \& Garritz, A. (2008). Undergraduate professors pedagogical content knowledge: the case of amount of substance. International Journal of Science Education, 30(10), 1389-1404.

Pajares, M. F. (1992). Teachers' beliefs and educational research: cleaning up a messy construct. Review of Educational Research, 62(3), 307.

Park, S., \& Chen, Y.-C. (2012). Mapping out the integration of the components of pedagogical content knowledge (PCK): examples from high school biology classrooms. Journal of Research in Science Teaching, 49(7), 922-941.

Park, S., \& Oliver, J. S. (2008). Revisiting the conceptualisation of pedagogical content knowledge (PCK): PCK as a conceptual tool to understand teachers as professionals. Research in Science Education, 38(3), 261-284.

Pfeffer, J., \& Sutton, R. I. (2013). The knowing-doing gap: how smart companies turn knowledge into action. Brighton, MA.

Putnam, R. T., \& Borko, H. (1997). Teacher learning: implications of new views of cognition. In B. Biddle, T. L. Good, \& I. F. Goodson (Eds.), International handbook of teachers and teaching, volume II (pp. 1223-1296). Dordrecht: Kluwer.

Schön, D. A. (1983). The reflective practitioner: how professionals think in action. New York: Basic Books.

Scott, P. H., Mortimer, E. F., \& Aguiar, O. G. (2006). The tension between authoritative and dialogic discourse: a fundamental characteristic of meaning making interactions in high school science lessons. Science Education, 90(4), 605-631.

Shulman, L. S. (1986). Those who understand: knowledge growth in teaching. Educational Researcher, 15(2), 4-14.

Shulman, L. S. (1987). Knowledge and teaching: foundations of the new reform. Harvard Educational Review, $57(1), 1-23$.

Stolk, M. J. (2013). Empowering chemistry teachers for context-based education. Towards a framework for design and evaluation of a teacher professional development programme in curriculum innovations. Unpublished doctoral dissertation, Utrecht University.

Taylor, B. W. (1987). Classroom discipline: a system for getting the administration to see discipline problems your way. Dayton: Southern Hills Press.

Van Driel, J. H., Bulte, A. M. W., \& Verloop, N. (2005). The conceptions of chemistry teachers about teaching and learning in the context of a curriculum innovation. International Journal of Science Education, 27(3), 303-322.

Van Driel, J. H., Bulte, A. M. W., \& Verloop, N. (2008). Using the curriculum emphasis concept to investigate teachers' curricular beliefs in the context of educational reform. Journal of Curriculum Studies, 40(1), 107-122.

Van Driel, J. H., \& Henze, I. (2012). Extended paper for PCK Summit, Colorado 2012. Retrieved from http://pcksummit.bscs.org.

Van Gelder, L., Peters, J. J., Oudkerk Pool, T., \& Sixma, J. (1973). Didactische analyse. Groningen: WoltersNoordhoff.

Verloop, N. (1992). Praktijkkennis van docenten: Een blinde vlek van de onderwijskunde [practical knowledge of teachers: a blind spot of educational theory]. Pedagogische studiën, 69, 410-423.

Verloop, N., Van Driel, J., \& Meijer, P. (2001). Teacher knowledge and the knowledge base of teaching. International Journal of Educational Research, 35(5), 441-461.

Weber, R. P. (1990). Basic content analysis. Newbury Park, CA: Sage.

Westbroek, H. (2005). Characteristics of meaningful chemistry education: the case of water quality. Unpublished doctoral dissertation, The Netherlands: Utrecht University.

Wongsopawiro, D. (2012). Examining science teachers' pedagogical content knowledge in the context of a professional development program. Leiden University, The Netherlands: Unpublished doctoral dissertation. 